www.jmscr.igmpublication.org

Impact Factor 5.84

Index Copernicus Value: 71.58

ISSN (e)-2347-176x ISSN (p) 2455-0450

crossref DOI: _https://dx.doi.org/10.18535/jmscr/v5i11.135

Journal Of Medical Science And Clinical Research

\title{
Early Complications in Total Radial Head Excision \& Radial Head Replacement in Comminuted Radial Head Fractures
}

\author{
Authors \\ Prof. Dr R.Neelakrishnan ${ }^{1}$, Dr P.Murali ${ }^{2}$
}

${ }^{* 1}$ Professor \& HOD of Orthopaedics, Rajah Muthiah Medical College \& Hospital, Annamalai University

${ }^{2}$ Postgraduate in Orthopaedics, Rajah Muthiah Medical College \& Hospital, Annamalai University

\begin{abstract}
Introduction: Comminuted radial head fractures represents one of the troublesome and unpredictable complications which leads to upper limb disability that orthopaedic surgeons face. The two current methods of managing comminuted radial head fracture are excision of the radial head and radial head prosthesis in this study.
\end{abstract}

Aim: To assess the early associated complications in radial head excision and radial head prosthesis.

Material \& Methodology: The study comprised of 20 patients with unstable elbow injuries, out of 20 cases, 3 cases treated with radial head prosthesis and 4 cases treated with radial head excision .study period was from september 2016 to October 2017 at Rajah Muthiah Medical College, Chidambaram.

Results: There were 7 cases with comminuted radial head fractures. The mean duration of immobilisation was 25.5 (range, 17-38) days. After physical therapy, the mean range of motion of the elbow improved to $130^{\circ}$ flexion (24\% recovery), $18^{\circ}$ extension (35\% recovery), $73^{\circ}$ supination $\left(142 \%\right.$ recovery), and $85^{\circ}$ pronation (25\% recovery). The greatest gain in range of motion occurred within 3 to 4 months.

Complications: included wrist pain, proximal migration of radius, heterotopic ossification, restricted rotational motion, degenerative articular changes, radioulnar synostosis in radial head excision. Implant deformation, implant loosening, synovitis, degenerative changes.

Conclusion: Every fracture pattern needs to be managed differently which will give enough stability to start early mobilisation .total radial head excision patients have higher complication rate.

Keywords: Comminuted radial head fractures, outcome, radial head excision and radial head prosthesis.

\section{Introduction}

Radial head fractures ${ }^{1}$ are a common fractures with an incidence of around 30 percent of adult fractures. Radial head fractures associated with bone and soft tissue injuries in the hand, wrist and forearm. The mason classification ${ }^{2}$ is useful to classify and guide for the management. Johnston described the comminuted radial head fracture with associated elbow dislocation as type 4 fracture to differentiate it from the isolated comminuted radial head fracture (type 3).prognosis and management for each fracture pattern will be different especially type fractures cannot have good results with open reduction internal fixation. king et al had poor results with internal fixation .total radial head excision alone shows good results in type 3 radial head fractures with stable elbow joint.

Type 3 fractures associated with Medial collateral ligament or interosseous membrane injury or type 
4 or type 4 equivalent fracture with ulnohumeral joint dislocation and essex lopresti fracture need radial head replacement with prosthesis ${ }^{3}$.

Soft tissue injuries plays a significant role in complication of such fractures. If the medial collateral ligament or interosseous membrane is injured then the radial head becomes a main stabilizer against valgus stress which can causes distal radio ulnar joint disruption and pain.

Morrey et al proposed that the radiocapitellar joint is the secondary stabilizer of the elbow joint against valgus stress.

Case - 1

Immediate X- ray

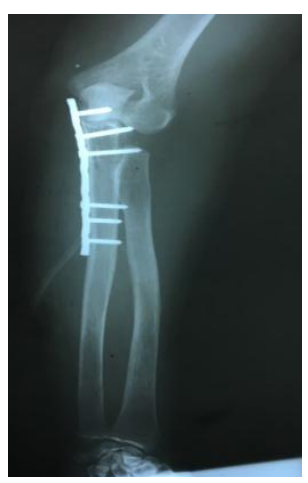

Follow up X-ray

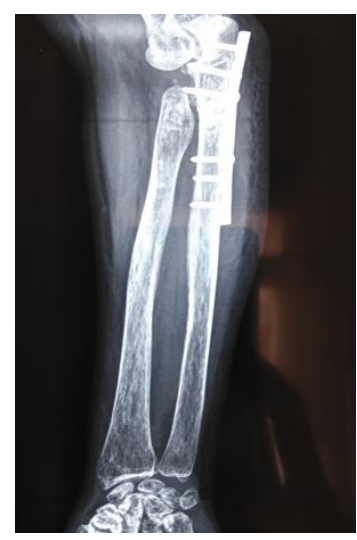

\section{Inclusion criteria}

1. Comminuted radial head fracture mason type 3.

2. Comminuted radial head fracture mason type 3 with MCL injury.

3. Comminuted radial head fracture mason type 4.

\section{Exclusion criteria}

1. Paediatric patients

2. Open injuries

3. Patient medically not fit for surgery

4. Patient not willing for surgery.
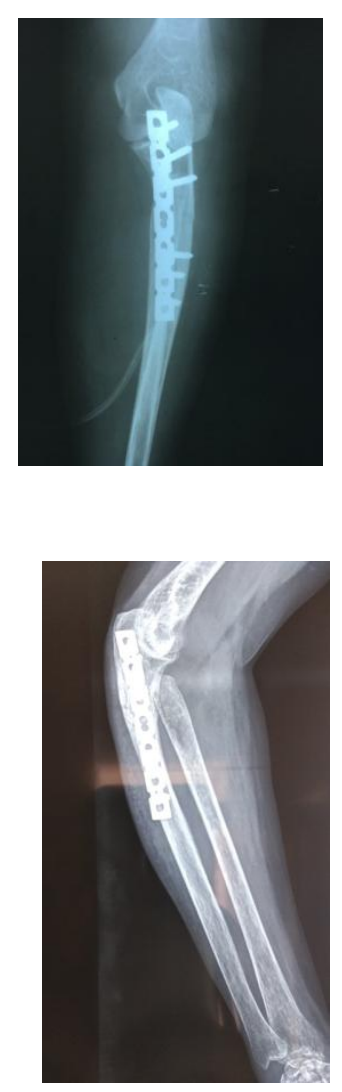

Radio Ulnar Synostosis

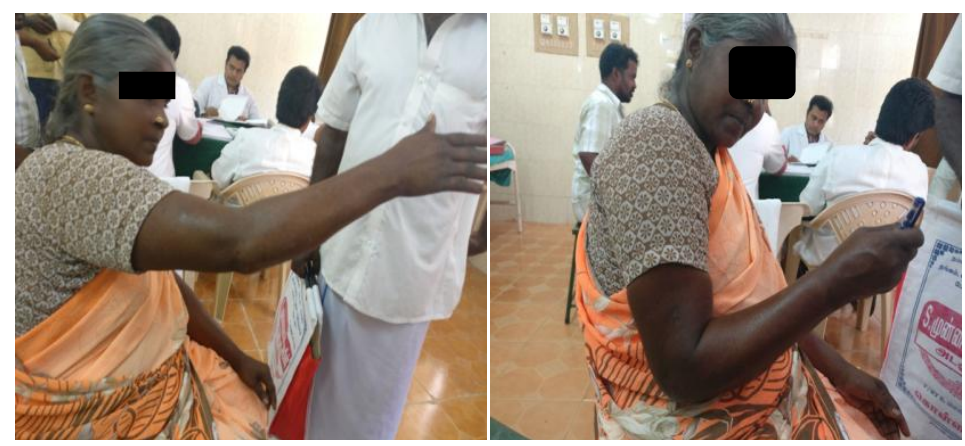


Case -2

Immediate $\mathrm{X}$ - ray

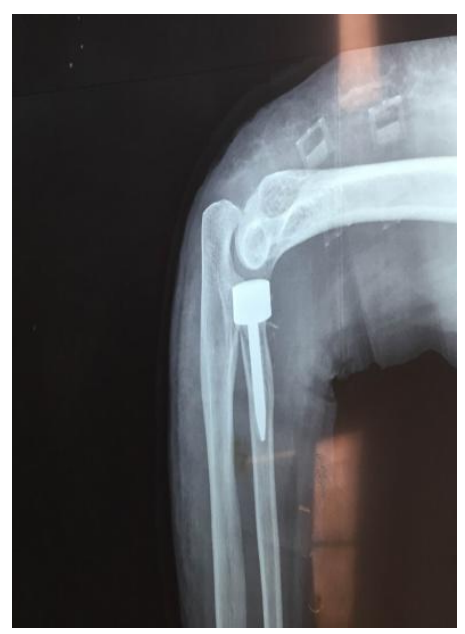

Follow up X-ray

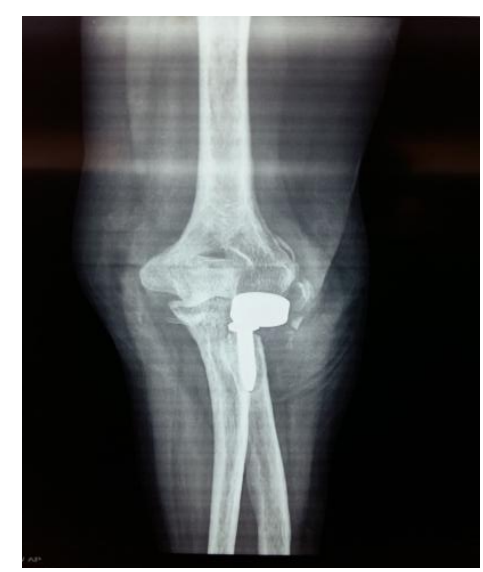

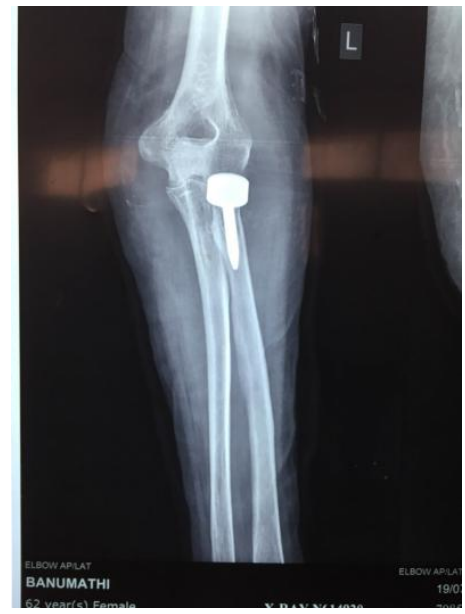

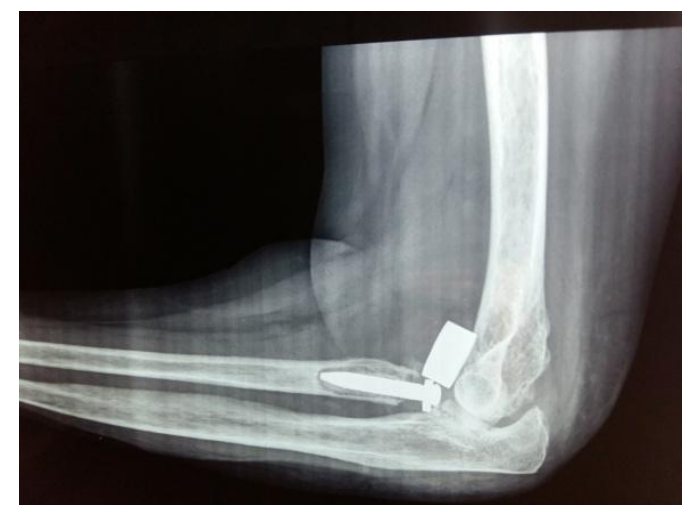

Table 1: type of fracture MASON- Classification

\begin{tabular}{|l|c|}
\hline Type of fracture & Number of patient \\
\hline TYPE III & 4 \\
\hline TYPE IV & 3 \\
\hline
\end{tabular}

Table 2: Complications In Radial Head Excision

\begin{tabular}{|l|r|}
\hline Wrist pain & 2 \\
\hline Radiounlar synostosis & 1 \\
\hline
\end{tabular}

Table 3: Complication in Radial Head Replacement

\begin{tabular}{|l|l|}
\hline Implant failure & 1 \\
\hline Arthritic changes & 2 \\
\hline
\end{tabular}

\section{Mechanism of injury}

Cutler states that direct trauma was the commonest mechanism of injury of radial head. Now over all accepted that indirect injury through the long axis of radius is most common cause. Direction of the force and the longitudinal trabecular pattern of the head is responsible for the longitudinal direction of the fracture pattern.

\section{Discussion}

Excision of the radial head in type 3 fracture is the generally accepted procedure. However unsatisfactory results following excision have led some surgeons to use prosthetic head. But generally not accepted. Residual loss of motion in the elbow with these fractures is usually due to damage to the capitellum articular surface against the radial 
head crushes. Gaston et al states that articular damage also due surgical procedure. Murray $^{3}$ consider that this loss of motion is due to the articular damage of the humerus and trochlear notch of the ulna and there must be also a severe soft tissue damage at the elbow joint. Initial injury often causes partial rupture of medial ligament, laceration of brachialis muscle and tearing of capsule followed by fibrous repair causes soft tissue contracture. Most common cause for the wrist pain is due to rupture of the distal radio unlar joint at the time of injury.

Mason type 4 carries the worst prognosis due to complete disruption of the joint and high incidence of new bone formation. It said that complication of the heteropic ossification can be reduced by excision of the radial head within $24 \mathrm{hrs}$ of injury. Gaston et al proved the above said.

\section{Conclusion}

Radial head fractures managed with radial head excision and replacement have been followed up clinically and radiologically to address the early complication. Early diagnosis and management have better results and lesser complications.

\section{References}

1. J.HARRINGTON, A.A.TOUNTAS Replacement of the radial head in the treatment of unstable elbow fractures; The british journal of accidental surgery vol 12/no.5.

2. GANESH F GUPTA, GEORGE LUCAS, DUSTAN L HAHN, Biomechanical and computer analysis of radial head prostheses; Journal shoulder elbow surgery January 1997.

3. G.W.JOHNSTON A follow up of one hundred cases of fracture of the head of the radius with a review of the literature; Fracture and orthopaedic service; Royal victoria hospital, Belfast 51-56.

4. RICHARD A SANDERS open reduction and internal fixation of comminuted radial head fractures; the American journal of sports medicine vol 14,No 2 . 